University of New Orleans

ScholarWorks@UNO

4-1993

\title{
Biochemical Correlates of Estivation Tolerance in the Mountainsnail Oreohelix (Pulmonata: Oreohelicidae)
}

\author{
Bernard Rees \\ University of New Orleans, brees@uno.edu
}

Follow this and additional works at: https://scholarworks.uno.edu/biosciences_facpubs

Part of the Biology Commons

\section{Recommended Citation}

Rees, B.B., and Hand, S.C. 1993. Biochemical correlates of estivation tolerance in the Mountainsnail Oreohelix (Pulmonata: Oreohelicidae). Biological Bulletin 184 (2): 230-242.

This Article is brought to you for free and open access by the Department of Biological Sciences at ScholarWorks@UNO. It has been accepted for inclusion in Biological Sciences Faculty Publications by an authorized administrator of ScholarWorks@UNO. For more information, please contact scholarworks@uno.edu. 


\section{Biochemical Correlates of Estivation Tolerance in the Mountainsnail Oreohelix (Pulmonata: Oreohelicidae)}

\section{B B Rees and S C Hand}

Biol Bull 184:230-242 (1993) http://biostor.org/reference/10562

\section{(c) (i) (5)}

Page images from the Biodiversity Heritage Library, http://www.biodiversitylibrary.org/, made available under a Creative Commons Attribution-Noncommercial License http://creativecommons.org/licenses/by-nc/2.5/ 


\title{
Biochemical Correlates of Estivation Tolerance in the Mountainsnail Oreohelix (Pulmonata: Oreohelicidae)
}

\author{
BERNARD B. REES ${ }^{1}$ AND STEVEN C. HAND \\ Department of Environmental, Population and Organismic Biology, University of Colorado, \\ Boulder, Colorado 80309-0334
}

\begin{abstract}
Biochemical changes occurring over 7 months of estivation were studied in two species of land snail. Oreohelix strigosa (Gould) and $O$. subrudis (Reeve), to determine whether differential mortality during estivation is related to different energetic strategies. Laboratorymaintained snails, which were fed ad libitum prior to estivation, were compared with snails collected from the field and induced to estivate without augmenting their energy reserves. In all groups, polysaccharide was catabolized early in estivation, and protein was the primary metabolic substrate after polysaccharide reserves were depleted. Lipid was catabolized at a low rate throughout estivation. Rates of catabolism were largely statistically equivalent between species. Urea and purine bases accumulated during estivation as a result of protein catabolism, with the former being quantitatively more important. In both laboratory-maintained and field-collected snails, the rate of urea accumulation was greater in $O$. subrudis, resulting in higher tissue urea contents in this species at the end of the 7 -month experiment. The tissue concentrations of urea at 7 months ranged from about 150 to $300 \mathrm{~m} M$ and were positively correlated $(r=0.99$, $P=0.006$ ) with mortality in these snails. Methylamine compounds, a class of compounds that can offset disruptive effects of elevated urea, were measured in one group of $O$. strigosa at 7 months of estivation and found to be low relative to urea levels. We suggest, therefore, that in the absence of elevated levels of counteracting compounds, urea may reach toxic levels and may be one factor limiting the duration of estivation that is survived by these land snails.
\end{abstract}

Received 2 June 1992; accepted 9 December 1992.

'Present address: Hopkins Marine Station, Department of Biological Sciences, Stanford University, Pacific Grove, CA 93950.

\section{Introduction}

The success of gastropod mollusks in terrestrial habitats has been due to various structural, physiological, and behavioral specializations (Riddle, 1983). One specialization that is well developed among the pulmonate land snails is the capacity to enter the dormant state of estivation during periods of hot and dry environmental conditions. By entering estivation, snails are able to endure potentially desiccating climatic conditions until the return of more favorable conditions. Some species are capable of estivating for remarkable periods of time, ranging up to several years in duration (Stearns, 1877; Machin, 1967).

There are limits to the duration of estivation that can be tolerated, though, and mortality eventually increases as estivation is prolonged. Because there is no intake of foodstuffs during estivation, the period of estivation that can be survived may be limited by the exhaustion of endogenous energy reserves (Pomeroy, 1969; Schmidt-Nielsen et al., 1971). Metabolic rate reduction, which would serve to prolong the energy stores of the animal, occurs during estivation, and desert-dwelling species display lower rates than species from more mesic environments (Schmidt-Nielsen et al., 1971; Herreid, 1977; Rees and Hand, 1990). These observations have been taken as supporting the idea that energy reserves are limiting. But since the rates of metabolism and evaporative water loss are highly correlated in land snails (Barnhart, 1986), the reduction of metabolic rate may reflect an adaptation to conserve water rather than energy. A comparison of survivorship in snails with differing levels of energy reserves prior to estivation would more clearly address the question of energy limitation.

The duration of estivation may also be limited by the accumulation of noxious end-products of protein catabolism. Depending upon the species and activity pattern. 
land snails can dispose of nitrogen derived from protein catabolism in the form of uric acid and other purines, urea or gaseous ammonia (Bishop et al. 1983). In species that produce urea, this compound can reach very high levels in the tissues during estivation: levels of $260 \mu \mathrm{mol}$ $\mathrm{g}^{-1}$ wet mass ( $\mathrm{ca} .300 \mathrm{~m} / /$ ) have been measured in the tissues of Bulimulus dealhatus (Horne, 1971), and 440 $\mathrm{m} M$ in the blood of Strophocheilus oblongus (Tramell and Campbell, 1972). At these levels, urea can have significant deleterious effects on the function of several biological processes (Yancey et al. 1982; Yancey, 1985; Yancey and Berg. 1990). In other organisms displaying elevated tissue contents of urea, methylamine compounds, which can offset the disruptive effects of urea, are commonly accumulated. It is not known whether methylamines accumulate during estivation in snails with high urea. If not, then urea could reach toxic levels and be a factor limiting the duration of estivation.

In the present study, we have investigated the extent to which the exhaustion of energy reserves and the accumulation of nitrogenous compounds correlate with mortality differences observed during laboratory estivation in two species of the mountainsnail Oreohelix. We measured the biochemical composition of $O$ strigosa and $O$. subrudis over a 7 -month period of laboratory estivation. From these data we have estimated rates of catabolism of protein, polysaccharide, and lipid. We compared snails that had been fed ad libitum prior to estivation with snails that had been collected from the field and induced to estivate without feeding to ascertain the effects of elevated energy stores. We also measured the accumulation of nitrogenous end-products of protein catabolism. Estivating snails were found to accumulate large quantities of urea. and we measured the tissue content of methylamines to address the possible counteraction of urea effects by these compounds.

Finally, tolerance to desiccation under laboratory conditions has been correlated with the distribution of a variety of land snail species in nature, with the more tolerant species occurring in drier habitats (Machin, 1967; Cameron, 1970: Arad et al, 1989). The genus Oreohelix is widely distributed in western North America, ranging from mesic riparian areas to semi-arid habitats (Bequaert and Miller, 1973; Rees, 1988). In the present study, we have characterized the climatic conditions prevailing at three collection sites in western Colorado, and we have evaluated the distribution of $O$. strigosa and $O$. subrudis at these sites in light of their differing capacities for prolonged laboratory estivation.

\section{Materials and Methods}

\section{Collection sites}

Oreohelix spp. were collected in western Colorado along Mitchell and East Rifle Creeks. The snails from the
Mitchell Creek drainage were collected along the east bank of the creek, approximately $100 \mathrm{~m}$ downstream of the Mitchell Creek Fish Hatchery $\left(39^{\circ} 42^{\prime}, 107^{\circ} 22 \mathrm{~W}\right.$; 1850 $\mathrm{m})$, near Glenwood Springs, Colorado. Along the East Rifle Creek, snails were collected from areas located approximately $1 \mathrm{~km}$ upstream and $3 \mathrm{~km}$ downstream of the Rifle Falls Fish Hatchery $\left(39^{\circ} 42^{\prime}, 107^{\circ} 42^{\prime} \mathrm{W} ; 2100 \mathrm{~m}\right)$. The upstream site was about $25 \mathrm{~m}$ west of the creek among rock slide rubble in Rifle Gorge, and the downstream site was adjacent to the creek at the Rifle Falls campground. The three collection locales will be referred to as the Mitchell Creek, Rifle Gorge, and Rifle Falls sites. The Mitchell Creek site has previously been referred to as the Glenwood Springs collection site (Rees, 1988).

The climatic conditions prevailing during the summer months in the Mitchell Creek and East Rifle Creek drainages are shown in Table I. Further information on the conditions at the two Rifle sites was obtained with a handheld temperature-humidity sensor on several days during the summers of 1990 and 1991. Measurements were made $2-5 \mathrm{~cm}$ above the ground between 06:00 and 08:00, and again between 13:00 and 16:00 h. On average, the early morning humidity was $4 \%$ higher, and the mid-day humidity was $5 \%$ higher, at the Rifle Falls than at the Rifle Gorge site. Taken together, these data illustrate that moisture availability at the three collection sites decreases in the order Mitchell Creek $>$ Rifle Falls $>$ Rifle Gorge.

\section{Animals and species identification}

Snails were collected in June and August of 1987 and in November of 1989. They were either sacrificed immediately for determination of the biochemical composition of animals in the field, or brought into the laboratory and used for estivation studies (see below). The average shell-free tissue mass of snails prior to estivation in the laboratory was $0.453 \pm 0.014 \mathrm{~g}$ (SEM, $\mathrm{n}=63$ ) for $O$. strigosa and $0.394 \pm 0.013 \mathrm{~g}$ for $O$. subrudis $(\mathrm{n}=41)$. Both species are hermaphroditic and bear live young. Only individuals without developing young in their oviducts were used in this study.

After the snails had been sacrificed for biochemical analyses (see below), the species was determined by starch gel electrophoresis of proteins (Rees, 1988). During the present study, additional, faster-migrating alleles were resolved in $O$. strigosa at the phosphoglucomutase and phosphoglucose isomerase loci. This finding does not compromise the utility of this technique in species determination, however, as the occurrence of the slow alleles at these loci remains diagnostic of $O$. subrudis. Individuals that were not electrophoretically genotyped (snails collected in June 1987 and those which died during the estivation series) were separated into species by their shell morphology (Rees, 1988). 
Table I

Climatic conditions during the summer of 1990 in the Mitchell Creek and East Rifle Creek drainages

\begin{tabular}{|c|c|c|c|c|c|c|c|}
\hline Site & Month & $\begin{array}{l}\text { Daily low } \\
\text { temp }\left({ }^{\circ} \mathrm{C}\right)\end{array}$ & $\begin{array}{l}\text { Daily high } \\
\text { temp ( }\left({ }^{\circ} \mathrm{C}\right)\end{array}$ & $\begin{array}{c}\text { Daily low } \\
\text { RH (\$) }\end{array}$ & $\begin{array}{c}\text { Daily high } \\
\text { RH (\%) }\end{array}$ & $\begin{array}{c}\text { Rainfall } \\
\text { (mm) }\end{array}$ & $\begin{array}{c}\text { Normal } \\
\text { rainfall }(\mathrm{mm})\end{array}$ \\
\hline \multirow[t]{4}{*}{ Mitchell Creek } & June & $8 \pm 2$ & $25 \pm 4$ & $30 \pm 8$ & $70 \pm 6$ & 22 & 31 \\
\hline & July & $11 \pm 2$ & $23 \pm 2$ & $37 \pm 8$ & $75 \pm 6$ & 48 & 30 \\
\hline & August & $10 \pm 2$ & $23 \pm 3$ & $36 \pm 9$ & $72 \pm 8$ & 15 & 36 \\
\hline & June-Aug & $10 \pm 2$ & $23 \pm 3$ & $35 \pm 9$ & $72 \pm 7$ & 85 & 97 \\
\hline \multirow[t]{4}{*}{ East Rifle Creek } & June & $11 \pm 3$ & $28 \pm 5$ & $26 \pm 6$ & $52 \pm 15$ & 18 & 21 \\
\hline & July & $13 \pm 2$ & $28 \pm 2$ & $31 \pm 6$ & $65 \pm 15$ & 31 & 19 \\
\hline & August & $12 \pm 2$ & $27 \pm 4$ & $30 \pm 7$ & $61 \pm 17$ & 7 & 32 \\
\hline & June-Aug & $12 \pm 2$ & $28 \pm 4$ & $29 \pm 7$ & $60 \pm 17$ & 56 & 72 \\
\hline
\end{tabular}

Temperature and humidity readings were made continuously with hygrothermographs located at the Mitchell Creek and Rifle Falls Fish Hatcheries. Hygrothermographs were enclosed in Stevenson-style temperature cabinets approximately 10 cm above the ground and were calibrated against a hand-held temperature-humidity sensor that had been certified by the National Bureau of Standards. The data reported for June were recorded between June 5 and June 30: data for July and August are from all days in these months. Temperature and humidity are reported as the means and one standard deviation of the daily values, All monthly temperature and relative humidity averages are significantly different between field sites. except for June daily low relative humidity ( 1 -test, $P<0.05$ ). Monthly rainfall data for 1990 and normal rainfall (averages for the years $1951-1980$ ) were recorded in the nearby communities of Glenwood Springs and Rifle (ca.. 5 and $20 \mathrm{~km}$ from fish hateheries, respectively) and are taken from Climatological Data. Colorado (U.S. Department of Commerce).

\section{Estivation series}

Two experiments were carried out to assess the effects of estivation on the biochemical composition of these snails. One was performed with snails collected in November of 1989 and fed ad libitum for 2 months prior to estivation. These snails were kept in damp terraria and fed lettuce and carrots. Chalkboard chalk was provided as a source of calcium. This feeding regime was designed to saturate the energy reserves of the snails prior to estivation and to minimize the variation in nutritional status due to differing conditions at the collection sites. After 2 months, these snails were transferred to dry terraria without food, which induced estivation. These snails are referred to as the laboratory-maintained group. In the other experiment, snails collected in August 1987 were brought into the lab and induced to estivate immediately by placement in dry terraria. In this experiment, we wanted to determine the effect of estivation on snails that did not have their energy reserves augmented by laboratory feeding. These snails are referred to as the field-collected snails. In both series, snails were maintained at room temperature $\left(23-28^{\circ} \mathrm{C}\right)$ and humidity $(\mathrm{ca} .20-60 \%)$ for the duration of the experiment. Under these conditions, snails were inactive within 2 days after being transferred to dry conditions, and there was no indication that any of the animals became active again once they had entered quiescence. Photoperiod was not controlled.

\section{Preparation of snails for chemical analyses}

Snail extracts were prepared and maintained at $0-4^{\circ} \mathrm{C}$ unless otherwise stated. Chemicals and biochemicals were of reagent grade, and water was purified with a Milli-Q Reagent Water System (Continental Water Systems, Inc.).

At the start of the experiments and at 1, 2, 4, and 7 months following entry into estivation, snails were sampled randomly from the terraria. An additional sampling interval at 10 days was included in the experiment with the field-collected snails. The shell diameter of each individual was measured, and the snails were then dissected from their shells, briefly blotted, and frozen in liquid nitrogen. Tissues were kept at $-70^{\circ} \mathrm{C}$ until biochemical analyses could be performed, at which time a small portion (5-15 mg) of the digestive gland was removed for electrophoresis, and the remainder of the tissue was lyophilized to a constant dry mass. The difference between fresh tissue mass and dry tissue mass was recorded as tissue water. Dry tissues were then pulverized with a mortar and pestle and divided into two subsamples: one fraction (approximately $40 \mathrm{mg}$ ) was used for determination of protein, DNA, polysaccharide, urea, and for the lab-maintained snails, purines; and the other fraction $(10-25 \mathrm{mg})$ was kept for lipid analysis. At the later time points in the estivation series, individuals were commonly less than 50 mg dry mass. This small amount of dry tissue could not be divided, so lipid was not measured in these individuals.

Extracts for the determination of protein, DNA, polysaccharide, urea and purines were prepared as follows. Dry tissues were homogenized in $1.0 \mathrm{ml}$ of ice cold $1 \mathrm{~N}$ perchloric acid with a glass homogenizer. Two $50 \mu \mathrm{l}$ aliquots of the perchloric acid homogenate were removed: one was combined with $0.95 \mathrm{ml} 0.5 \mathrm{~N} \mathrm{NaOH}$ and saved at $-70^{\circ} \mathrm{C}$ for protein assays; and the other was combined with $0.95 \mathrm{ml} 0.5 \%(\mathrm{w} / \mathrm{v})$ lithium carbonate and saved at 
$-70^{\circ} \mathrm{C}$ for purine analysis. The remainder of the perchloric acid extract was centrifuged at $10,000 \times \mathrm{g}$ for 15 $\mathrm{min}$. The pellets were washed once with $0.7-0.8 \mathrm{ml}$ of 1 $N$ perchloric acid and centrifuged as above. The perchloric acid insoluble material was saved for DNA measurement. Perchloric acid supernatants for each individual were pooled, neutralized with $5 \mathrm{M} \mathrm{K}_{2} \mathrm{CO}_{3}$, and centrifuged at $10,000 \times g$ for $10 \mathrm{~min}$ to remove perchlorate salts. Two hundred to $400 \mu \mathrm{l}$ of the neutralized extract was combined with two volumes of $95 \%$ ethanol and stored at $-70^{\circ} \mathrm{C}$ for polysaccharide assays, and the remainder was saved at $-70^{\circ} \mathrm{C}$ for urea measurements.

\section{Biochemical analyses}

Protein was measured by the method of Lowry et al. (1951), as modified by Peterson (1977), with bovine serum albumin as the standard. For calculations of nitrogen balance, it was necessary to determine the mass of nitrogen in snail protein. The protein in a perchloric acid homogenate was recovered by centrifugation after the nucleic acids had been digested by heating (see below). Lipid was removed by washing the PCA-insoluble material with methanol. The amount of nitrogen in the PCA-insoluble fraction was determined by a micro-Kjeldahl procedure that includes direct nesslerization of ammonia following digestion of the proteins (Koch and McMeekin, 1924). The Nessler reagent was obtained from Sigma Chemical Company. The amount of nitrogen in protein determined in this manner was not different in the two species and was found to account for $16.8 \pm 0.9 \%$ (S.D., n $=4$ ) of the protein mass measured by the Lowry assay.

DNA was determined by the diphenylamine assay of Burton (1956) with modifications suggested by Giles and Myers (1965). Briefly, perchloric acid insoluble material was suspended in $1.0 \mathrm{ml} 1.5 \mathrm{~N}$ perchloric acid and heated at $70^{\circ} \mathrm{C}$ for $20 \mathrm{~min}$. Following centrifugation at 10,000 $\times g$ for $20 \mathrm{~min}$, an aliquot $(50-100 \mu \mathrm{l})$ of the supernatant was brought to $2.5 \mathrm{ml}$ with $1.5 \mathrm{~N}$ perchloric acid and combined with $1.5 \mathrm{ml} 4 \%(\mathrm{w} / \mathrm{v})$ diphenylamine made in glacial acetic acid and $0.1 \mathrm{ml} 0.16 \mathrm{mg} \mathrm{ml}^{-1}$ acetaldehyde made in water. The color was allowed to develop for 20 $h$ in the dark at room temperature. To correct for nonspecific color development, an absorbance difference $\left(\mathrm{A}_{600}\right.$ $-A_{700}$ ) was determined for each sample. Calf thymus DNA was the standard.

Polysaccharide (glycogen plus galatogen), which precipitated in the ethanolic extract, was collected by centrifugation at $10,000 \times g$ for $20 \mathrm{~min}$, washed once with $1.0 \mathrm{ml} \mathrm{95 \%} \mathrm{ethanol} \mathrm{and} \mathrm{centrifuged} \mathrm{again.} \mathrm{The} \mathrm{pellets}$ were air-dried and redissolved in $1.0 \mathrm{ml}$ water by heating at $70^{\circ} \mathrm{C}$. Polysaccharide was measured by the anthrone method described by Jermyn (1975), except that the additions of hydrochloric and formic acid to the samples were omitted. Polysaccharide content was expressed as $0.9 \times$ glucose mass.

For urea analysis, samples were thawed and clarified by centrifugation at $10,000 \times g$ for $10 \mathrm{~min}$. Urea was measured colorimetrically as ammonia after treatment of the samples with urease (Sigma Diagnostic Kit No. 640). Blanks without urease were subtracted from each sample.

Purine bases were analyzed with high performance liquid chromatography essentially as described by Simmonds and Harkness (1981). A LDC/Milton Roy HPLC system was employed in conjunction with a Waters $\mu$ Bondapak C -18 column $(30 \mathrm{~cm} \times 3.9 \mathrm{~mm}$ i.d. $)$. The lithium carbonate solutions were thawed, diluted, neutralized, and filtered through Gelman Supor $0.45 \mu \mathrm{m}$ membrane filters. Twenty $\mu \mathrm{l}$ were injected onto the column, and purines were eluted isocratically with a buffer of $4 \mathrm{~m} M /$ potassium phosphate ( $\mathrm{pH} 3.6$ ) containing $1 \%(\mathrm{v} / \mathrm{v})$ methanol. Absorbance was monitored at $265 \mathrm{~nm}$, and uric acid, guanine and xanthine were quantified by integration of peak area.

Total lipid was determined after extraction of the tissues in chloroform:methanol (Folch et al., 1957: Ways and Hanahan, 1964). For each snail, lyophilized tissues were homogenized in $4 \mathrm{ml}$ chloroform:methanol (2:1) with a Virtis micro-ultrashear apparatus for $1 \mathrm{~min}$ and filtered through a fritted disc funnel. The residue was rehomogenized in $4 \mathrm{ml}$ chloroform: methanol and filtered. The residue was finally washed with another $2 \mathrm{ml}$ of chloroform: methanol and the filtrates combined. The filtered chloroform:methanol homogenate was mixed with 0.25 volume $0.88 \%(\mathrm{w} / \mathrm{v}) \mathrm{KCl}$ in water, and after separation, the aqueous phase was aspirated. The remaining organic phase was mixed with 0.25 volume methanol:water $(1: 1)$, and the aqueous phase was aspirated after separation. The organic phase was then decanted into a pre-weighed aluminum planchet and evaporated to dryness under a stream of nitrogen. The dried lipid was held over Drierite a further $24 \mathrm{~h}$ and weighed to the nearest $0.1 \mathrm{mg}$.

In one group of estivating snails, methylamine compounds were measured by reineckate precipitation protocol modified from Kermack et al. (1955). Lyophilized tissues from a whole snail were homogenized in 30 volumes of $40 \%$ ethanol and centrifuged at $20,000 \times g$ for $15 \mathrm{~min}$. The pellet was washed with another 30 volumes of $40 \%$ ethanol, and the combined supernatants were boiled for $10 \mathrm{~min}$ to precipitate proteins. The ethanolic extract was centrifuged at $10,000 \times g$ for $20 \mathrm{~min}$, lyophilized, and redissolved in $1.0 \mathrm{ml} 0.1 \mathrm{~N} \mathrm{HCl}$. Saturated ammonium reineckate, prepared in water and titrated to $\mathrm{pH}$ I with $5.0 \mathrm{~N} \mathrm{HCl}$, was added to the each sample in the ratio $3: 1$ (reineckate:sample). Reineckate salts were allowed to precipitate at $4^{\circ} \mathrm{C}$ overnight and were collected by filtration on polycarbonate membrane filters (Nucleopore, $0.2 \mu \mathrm{m}$ ). After washing the precipitate three times with $3 \mathrm{ml}$ diethyl ether, the precipitate and membrane 


\begin{tabular}{|c|c|c|c|c|}
\hline \multirow{2}{*}{ Compound } & \multicolumn{2}{|c|}{ O. strigosa } & \multicolumn{2}{|c|}{ O subrudis } \\
\hline & $\mathrm{mg} \mathrm{g}^{-1}$ dry mass & 5 dry mass & $m g g^{-1}$ dry mass & $\%$ dry mass \\
\hline Protein & $512.6 \pm 19.2$ & 51.3 & $509.4 \pm 13.7$ & 50.9 \\
\hline Polysaccharide & $216.2 \pm 11.3$ & 21.6 & $230.1 \pm 8.8$ & 23.0 \\
\hline Lipid & $70.3 \pm 1.4^{*}$ & 7.0 & $78.2 \pm 1.9$ & 7.8 \\
\hline \multirow[t]{2}{*}{ DNA } & $14.9 \pm 0.3$ & 1.5 & $16.7 \pm 0.5$ & 1.7 \\
\hline & $\mu \mathrm{mol} \mathrm{g} \mathrm{g}^{-1} \mathrm{dry}$ mass & $\%$ dry mass & $\mu \mathrm{mol} \mathrm{g} \mathrm{g}^{-1} \mathrm{dry}$ mass & $\%$ dry mass \\
\hline Urea & $0.98 \pm 0.29^{*}$ & $<0.1$ & $2.20 \pm 0.76$ & $<0.1$ \\
\hline Uric acid & $55.1 \pm 3.9$ & 0.9 & $45.1 \pm 4.0$ & 0.8 \\
\hline Guanine & $17.1 \pm 1.9$ & 0.3 & $10.3 \pm 1.2$ & 0.2 \\
\hline Xanthine & $7.1 \pm 0.6$ & 0.1 & $8.2 \pm 0.9$ & 0.1 \\
\hline Total dry mass accounted for & & 82.7 & & 84.5 \\
\hline
\end{tabular}

Values are given as the mean and standard error of the mean. The sample sizes were $27 O$ strigosa and $21 O$ subrudis, except for the lipid analyses. where sample sizes were 18 and 12 for $O$ strigosa and $O$ subrudis, respectively. Asterisks indicate that species means for these biochemical constituents are significantly different.

were dissolved in $70 \%$ acetone, and the absorbance was read at $520 \mathrm{~nm}$. Betaine was the standard.

Following the above protocols, the recoveries of known quantities of protein. DNA, urea, uric acid, guanine, xanthine, and lipid were $>88 \%$, and we did not correct the results for differences in recovery. In the case of polysaccharide, this protocol led to a $77 \pm 2.5 \%$ (S.D.. $n=4$ ) recovery of glycogen standards, and the polysaccharide content of snails was corrected accordingly.

\section{Data analysis}

Examination of the total tissue contents of various biochemical compounds revealed a large degree of variation due to size differences among individuals. For snails prior to estivation (both laboratory-maintained and field-collected), biochemical constituents were expressed in terms of dry mass in order to standardize for size differences. Equality of sample variances was tested with Bartlett's Box-F (Zar, 1984), and differences among group means were evaluated with parametric or nonparametric analyses of variance accordingly (Zar, 1984). A posteriori testing was done with Scheffe's or Dunn's multiple comparison tests (Zar, 1984).

During estivation, considerable dry mass was lost, so some variable other than dry mass was required as an index of snail size for standardization of biochemical composition. Data from non-estivating, laboratorymaintained snails showed that the relationship between shell diameter and snail size was quite good: coefficients of determination $\left(r^{2}\right)$ for regressions of whole tissue and dry tissue mass versus shell diameter were 0.763 and 0.784 . respectively. Furthermore, when all snails were consid- ered, there was no effect of duration of estivation on shell diameter (analysis of variance, $P=0.969$ ), suggesting that shell diameter neither increases nor decreases during estivation. Therefore, tissue mass, water, and biochemical contents of estivating snails were adjusted to a snail of average shell diameter $(15.63 \mathrm{~mm})$ based upon the slopes of regression equations describing the relationship between each component and shell diameter. For each species, the rates of change in these adjusted values during various intervals of estivation were then determined by regression analysis. Differences between species-specific rates of change were evaluated with the test for homogeneity of slopes in an analysis of covariance package (Zar, 1984).

Correlations between various biochemical measurements and mortality at 7 months of estivation were analyzed with Pearson's product-moment correlation. All statistical analyses were performed with SPSS-X, version 4 (SPSS, Inc.), and a probability $\leq 0.05$ was considered as statistically significant. Unless otherwise stated, data are presented as means and one standard error of the mean (SEM).

\section{Results}

\section{Biochemical composition of laboratory-maintained Oreohelix}

Laboratory-maintained Oreohelix strigos $a$ and $O$. subrudis were composed of approximately $51 \%$ protein, $22-$ $23 \%$ polysaccharide, $7-8 \%$ lipid, and about $1.5 \%$ DNA (Table II). The levels of urea and purine bases were low prior to estivation. Urea averaged $1-2 \mu \mathrm{mol} \mathrm{g}^{-1}$ dry mass, comparable to the level reported in Bulimulus dealbatus prior to estivation (Horne, 1971). The levels of purine 
bases totaled to $64-79 \mu \mathrm{mol} \mathrm{g}^{-1}$ dry tissue, similar to the tissue contents of other non-estivating snails (Jezewska $e t$ al., 1963; Horne, 1971). On a molar basis, uric acid accounted for about $70 \%$ of the total purine, with guanine and xanthine accounting for approximately 20 and $10 \%$ of the total purine, respectively, in both $O$. strigos $a$ and $O$. subrudis. Hypoxanthine was not found in the tissues of these snails. Taken together, these compounds account for more than $80 \%$ of the dry mass of these snails. The unaccounted fraction is presumed to be other low molecular weight organic compounds (e.g., amino acids) and inorganic ash.

\section{Biochemical composition of field-collected Oreohelix}

Compared with the values obtained for laboratorymaintained snails, both $O$. strigos $a$ and $O$. subrudis displayed lower polysaccharide levels in the field-collected groups (Fig. 1A). Protein constituted a correspondingly larger portion of the dry mass in both species (Fig. IB), and lipid was somewhat higher in $O$. strigosa collected in the late summer (Fig. IC). These differences in biochemical composition reflect the effects of ad libitum feeding in the laboratory-maintained group and suggest that snails feed less regularly or on food of differing qualities in the field. Of the snails collected in the late summer, $O$. strigos $a$ displayed significantly higher levels of polysaccharide than $O$. subrudis. Differences in polysaccharide content may influence the capacity of these snails for long-term estivation (see Discussion).
Snails of either species collected late in the summer demonstrated much more variable urea contents than snails in the laboratory-maintained or early summer groups (Fig. 1D). Among the laboratory-maintained snails, only $17 \%$ had urea contents greater than $1 \mu \mathrm{mol}$ $\mathrm{g}^{-1}$ dry mass, and among the snails collected early in the summer, this percentage was $22 \%$. In these groups, the highest urea content measured was $11.7 \mu \mathrm{mol} \mathrm{g}^{-1}$ dry mass. Among the snails collected later in the summer, urea was higher than $1 \mu \mathrm{mol} \mathrm{g}^{-1}$ dry mass in $33 \%$ of the snails, and the highest value was $93.0 \mu \mathrm{mol} \mathrm{g}^{-1}$ dry mass. Since urea accumulates during estivation (see below), the occurrence of elevated urea in snails collected late in the summer suggests that many of these animals had been estivating in the field.

\section{Mortality during estivation}

Both species of Oreohelix experienced mortality during the later months of estivation. In the group of snails that had been maintained in the laboratory prior to estivation, 1 of the remaining $13 \mathrm{O}$. strigosa had died at 7 months, whereas 9 of 300 subrudis had died. For snails that were brought in from the field, the mortality at 7 months in both species was higher: 10 of $24 O$. strigosa had died, whereas 28 of $34 O$. subrudis had died. Among the fieldcollected snails, the proportion of dead $O$. subrudis at 7 months was significantly greater than the proportion in $O$. strigosa (G-test, $P<0.05$ ). These results demonstrate that $O$. strigesa tolerates extended periods of estivation in the laboratory better than $O$. subrudis.
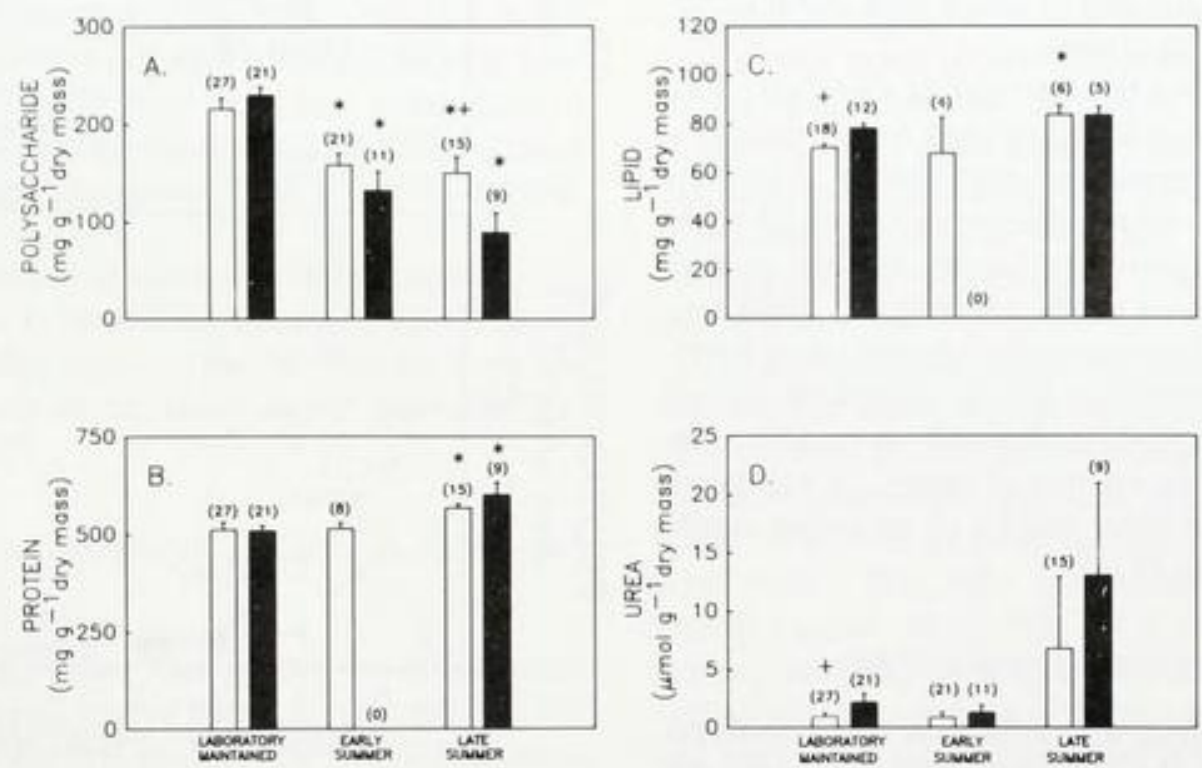

Figure 1. Biochemical composition of laboratory-maintained and field-collected $O$. strigosa (open bars) and $O$. subrudis (solid bars). A. Polysaccharide content. B. Protein content. C. Lipid content. D. Urea content. Error bars indicate one standard error of the mean. Asterisks indicate that the content of this constituent is significantly different from that measured in laboratory-maintained snails of the same species. and the crosses indicate that species means are significantly different for that sampling interval. 


\section{Analysis of changes during estivation}

We were interested in whether the two species have different rates of substrate depletion or end-product accumulation during estivation. Because variation in the size of individuals among the sampling intervals and between species would tend to obscure these rates, we have normalized the tissue mass, water content, and the content of biochemical constituents to an average snail size based upon shell diameter (see Materials and Methods). Note that, since dry mass, water content, and biochemical composition can be determined only once for any individual, the rates of change described below reflect average rates of loss or accumulation among groups of individuals rather than rates of change within individual snails. Furthermore, shell diameters were not measured on the fieldcollected snails sacrificed prior to estivation (day 0 ), and consequently the data for this group begin at 10 days of estivation.

\section{Loss of tissue mass and water during estivation}

Fresh tissue mass, dry tissue mass, and water decreased significantly in both species of Oreohelix during estivation. When tissue mass and water content data were corrected for size differences among individuals, rates of loss in the two species were not significantly different. The loss of tissue was characterized by parallel decreases in both dry tissue mass and tissue water. These losses were biphasic, occurring more quickly at the onset of estivation as the snails entered estivation, and then reaching a steady slower rate after the initial drop. By 7 months of estivation, the tissue mass and water content of snails were reduced by approximately $35 \%$ in all groups.

The loss of tissue water from estivating Oreohelix was not reflected in a decrease in the percent tissue water because the dry mass decreased proportionately. The percentage of tissue water remained between 78 and $81 \%$ for both species in both experimental series. In fact, among the laboratory-maintained snails, there was a slight but statistically significant increase in the percent tissue water over the 7 months of estivation despite the overall loss of water. Thus a constant percentage tissue water cannot be interpreted as indicating no loss of water, as has been assumed previously for other species of estivating snails (Schmidt-Nielsen et al., 1971).

\section{Catabolism of energy reserves during estivation}

Polysaccharide, protein, and lipid were all catabolized during estivation, but the substrates that were utilized changed as estivation proceeded (Figs. 2-4, Table III). Polysaccharide was the primary metabolic fuel for the initial months of estivation (Fig. 2). Snails that had been maintained in the laboratory began the estivation period with large polysaccharide stores, and in these snails, catabolism of this substrate continued for the first 4 months of estivation (Fig. 2A). During the first month of estivation. the rate of polysaccharide depletion was significantly faster in $O$. subrudis (Table III). Between 1 and 4 months, carbohydrate catabolism continued at moderate rates that were similar in the two species. After 4 months, the polysaccharide content of the snails was much reduced and its rate of utilization was correspondingly low. In the fieldcollected snails, the polysaccharide stores were smaller, and consequently they were depleted earlier (Fig. 2B). Although the initial rates of utilization were similar in the two species, carbohydrate lasted longer in $O$. strigosa, which had begun estivation with larger stores. As in the estivation series begun with laboratory-maintained snails, rates of polysaccharide utilization were much reduced during the later phases of estivation and statistically equivalent between species.

Upon depletion of the polysaccharide stores, net protein catabolism occurred (Fig. 3). In the laboratory-maintained snails, the onset of net protein depletion occurred at about 2 months of estivation (Fig. 3A). Before this time, no net
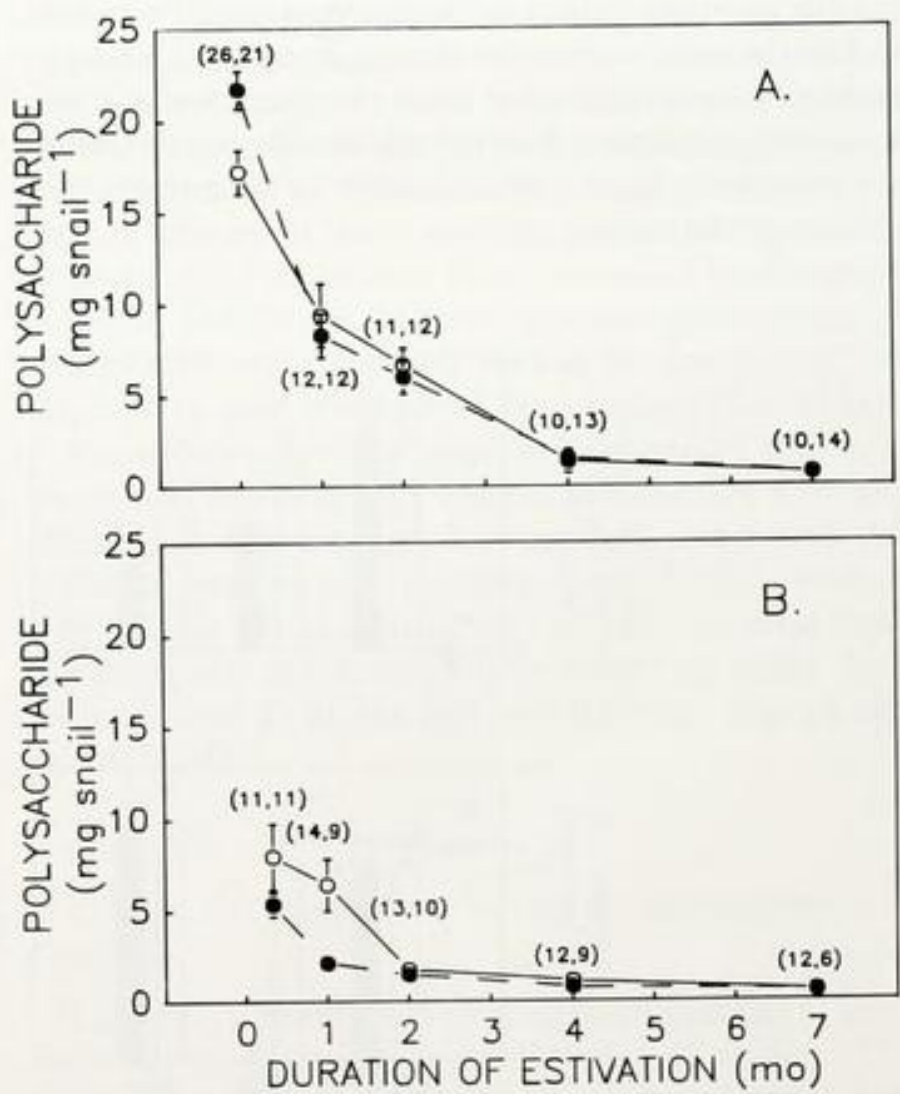

Figure 2. Polysaccharide content during estivation in $O$. strigosa $(O)$ and $O$. subrudis ( ). All values have been adjusted to a snail of average size based upon shell diameter. A. Laboratory-maintained snails. B. Fieldcollected snails. Sample sizes are given in parentheses with the value for $O$. strigosa appearing first. Bars indicate one standard error of the mean. 
Table III

Rates of polysaccharide, protein, and lipid catabolism and urea and purine accumulation in Oreohelix spp during estivation

\begin{tabular}{|c|c|c|c|c|c|}
\hline Compound & Experiment & Interval & O. strigosa & O. subrudis & $P$ \\
\hline \multirow[t]{5}{*}{ Polysaccharide } & A & $0-1$ month & $-7.81 \pm 2.16$ & $-13.45 \pm 1.71$ & 0.05 \\
\hline & A & $1-4$ months & $-2.66 \pm 0.59$ & $-2.23 \pm 0.41$ & 0.54 \\
\hline & A & 4-7 months & $-0.23 \pm 0.22^{\mathrm{Ns}}$ & $-0.27 \pm 0.12$ & 0.84 \\
\hline & B & 10 days -2 months & $-3.84 \pm 1.14$ & $-2.25 \pm 0.45$ & 0.23 \\
\hline & B & 2-7 months & $-0.23 \pm 0.08$ & $-0.18 \pm 0.04$ & 0.64 \\
\hline \multirow[t]{3}{*}{ Protein } & A & $0-2$ months & $-0.72 \pm 1.56^{\mathrm{NS}}$ & $0.95 \pm 0.97^{\mathrm{Ns}}$ & 0.37 \\
\hline & A & 2-7 months & $-1.95 \pm 0.63$ & $-2.73 \pm 0.35$ & 0.26 \\
\hline & B & 10 days -7 months & $-2.14 \pm 0.58$ & $-3.03 \pm 0.43$ & 0.26 \\
\hline \multirow[t]{2}{*}{ Lipid } & A & $0-7$ months & $-0.33 \pm 0.06$ & $-0.36 \pm 0.07$ & 0.78 \\
\hline & B & 10 days -7 months & $-0.11 \pm 0.12^{\mathrm{vs}}$ & $-0.67 \pm 0.21$ & 0.06 \\
\hline \multirow[t]{3}{*}{ Urea } & A & $0-2$ months & $0.98 \pm 0.21$ & $1.25 \pm 0.32$ & 0.47 \\
\hline & A & $2-7$ months & $6.20 \pm 0.87$ & $8.66 \pm 0.67$ & 0.03 \\
\hline & B & 10 days -7 months & $5.52 \pm 0.59$ & $8.75 \pm 0.53$ & $<0.01$ \\
\hline Uric acid & A & $0-7$ months & $0.43 \pm 0.12$ & $0.56 \pm 0.08$ & 0.36 \\
\hline Guanine & A & 0-7 months & $0.11 \pm 0.04$ & $0.15 \pm 0.02$ & 0.40 \\
\hline Xanthine & A & 0-7 months & $0.03 \pm 0.02^{\mathrm{NS}}$ & $0.05 \pm 0.02$ & 0.51 \\
\hline
\end{tabular}

Experiment A was done with snails after laboratory maintenance and experiment B with field-collected snails without prior laboratory maintenance Values for rates of catabolism (negative values) and accumulation (positive values) are slopes and their standard errors from regression equations of the adjusted tissue content of each compound versus length of estivation over the intervals indicated (see also Figs. 2-6). Units are mg snail ${ }^{-1} \mathrm{mo}^{-1}$ for polysaccharide, protein and lipid and $\mu \mathrm{mol}^{\text {snail }}{ }^{-1} \mathrm{mo}^{-1}$ for urea, uric acid, guanine and xanthine. All slopes were significantly different from zero, except where indicated (NS). $P$ values are from tests of equality of species-specific slopes.

protein catabolism occurred in either species, as indicated by the slopes of regression lines not significantly different from zero (Table III). After the onset of net protein catabolism, the rates of utilization were fairly linear throughout the remainder of the estivation period. Among the field-collected snails, significant protein catabolism occurred from the beginning of estivation (Fig. 3B). While species-specific rates were not significantly different, there was a trend toward lower rates of protein catabolism in $O$. strigosa in both experimental series (Table III) - a trend that likely influenced the rates of end-product accumulation (see below).

Lipid was catabolized at a low rate throughout the duration of estivation in both experimental series (Fig. 4). The rates of lipid utilization in the two species were not significantly different during the 7 -month estivation experiments (Table III).

\section{Accumulation of nitrogenous end-products and nitrogen balance}

With the onset of protein catabolism, the nitrogenous end-products, urea and purine bases, accumulated in the tissues of estivating snails (Figs. 5-6, Table III). The tissue levels of urea increased dramatically in both species of Oreohelix (Fig. 5). In the laboratory-maintained snails, protein was not catabolized early in estivation, and hence urea began to accumulate only after 2 months of estivation
(Fig. 5A). Between 2 and 7 months of estivation, the rate of accumulation was higher in $O$. subrudis than in $O$. strigosa (Table III). By 7 months of estivation, urea was $32.9 \pm 4.5 \mu \mathrm{mol}$ snail $^{-1}$ in $O$. strigosa $(\mathrm{n}=10)$ and 43.7 $\pm 3.1 \mu \mathrm{mol}$ snail ${ }^{-1}$ in $O$. subrudis $(\mathrm{n}=14)$. In the fieldcollected snails, urea began to increase almost immediately upon the commencement of estivation, reflecting the early dependence upon protein catabolism (Fig. 5B). Between 10 days and 7 months, the rate of urea accumulation in $O$. subrudis was again greater than in $O$. strigosa (Table III). The tissue urea contents of these snails after 7 months of laboratory estivation were $36.4 \pm 4.3 \mu \mathrm{mol} \mathrm{snail}^{-1}$ in $O$. strigosa $(\mathrm{n}=12)$ and $58.2 \pm 6.1 \mu \mathrm{mol}$ snail $^{-1}$ in $O$. subrudis $(\mathrm{n}=6)$.

The accumulation of purine bases was only measured in snails that had been maintained in the laboratory, and their patterns of change are shown in Figure 6. Over 7 months of estivation, uric acid increased by 3 to $4 \mu \mathrm{mol}$ snail $^{-1}$ (Fig. 6A), guanine increased by approximately 1 $\mu \mathrm{mol}^{\text {snail }}{ }^{-1}$ (Fig. 6B), and xanthine increased by less than $0.5 \mu \mathrm{mol}^{\text {snail }}{ }^{-1}$ (Fig. 6C). Hence the sum of the purines increased by only 5 to $6 \mu \mathrm{mol}$ snail $^{-1}$. Over the 7-month estivation period, the rates for uric acid, guanine and xanthine accumulation were not statistically different between the two species (Table III).

Ammonia production was measured as described by Speeg and Campbell (1968), except that estivating snails were kept in a closed chamber for a period of two days. 

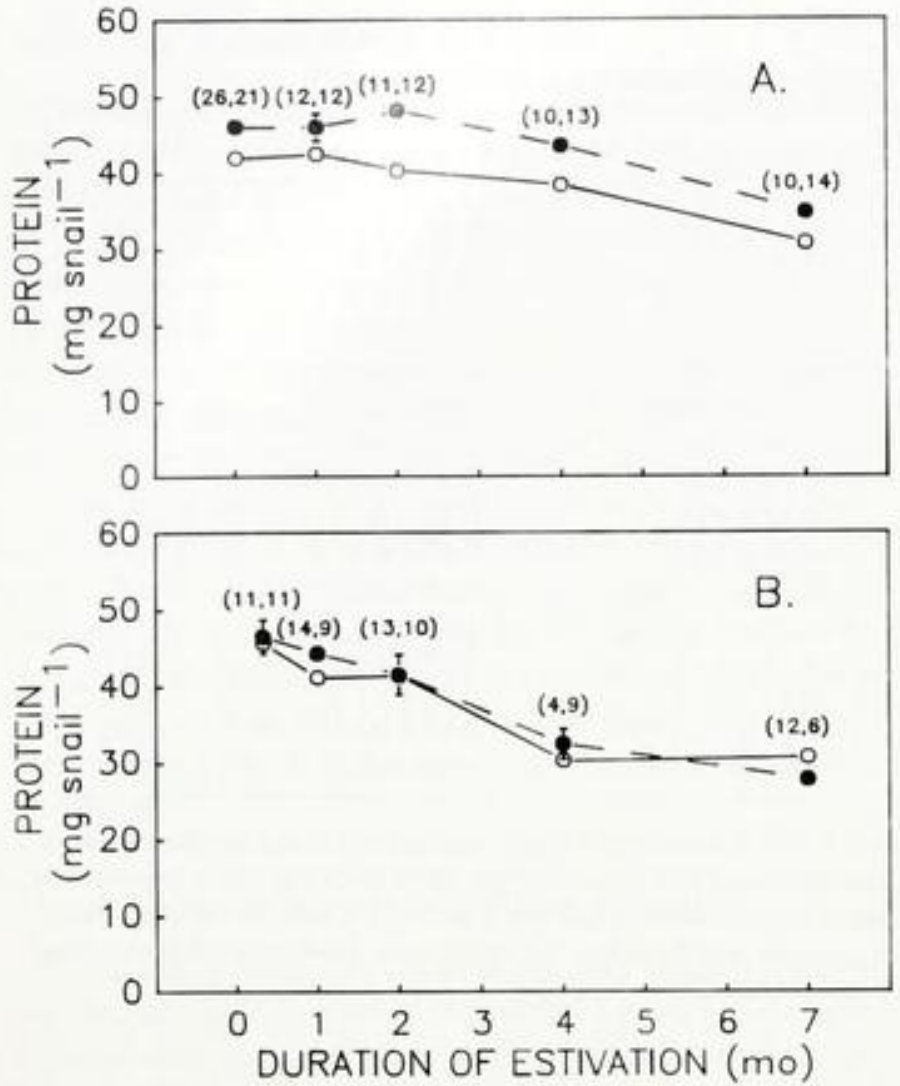

Figure 3. Protein content during estivation in $O$. strigosa $(O)$ and $O$. subrudis ( ). All values have been adjusted to a snail of average size based upon shell diameter. A. Laboratory-maintained snails. B. Fieldcollected snails. Sample sizes are given in parentheses with the value for $O$ strigosa appearing first. Bars indicate one standard error of the mean.

Over this period, the amount of ammonia produced by 8 snails of either species was below the limit of detection ( $0.02 \mu$ mole).

\section{Levels of urea-counteracting solutes}

Methylamine compounds were measured in one group of field-collected $O$. strigos $a$ after 7 months of estivation and found to be $2.68 \pm 0.27 \mu \mathrm{mol} \mathrm{snail}^{-1}(\mathrm{n}=5)$. HPLC analyses of selected extracts of both species have shown that betaine is the predominant methylamine compound, and that polyhydric alcohols, another class of protective compounds, do not significantly accumulate in snail tissues during estivation (data not shown).

\section{Discussion}

In the present study, we undertook an analysis of the biochemical changes that occur in Oreohelix strigosa and $O$. subrudis during a period of laboratory estivation. The temporal nature of substrate utilization and nitrogenous end-product accumulation were described for the first time in congeneric species of land snails that are dissimilar in their capacity for long-term estivation. Differences in the patterns of biochemical changes may account, in part, for the observed difference in mortality. Below, we evaluate the relationships between mortality and both the exhaustion of energy stores and the accumulation of nitrogenous end-products of protein catabolism. We also discuss the distributions of these Oreohelix species in the field in light of their different survivorship during desiccation stress.

\section{Mortality and exhaustion of energy stores}

If the duration of estivation is limited by the depletion of energy storage compounds during estivation, then snails with larger stores prior to estivation would be predicted to survive estivation proportionately longer. We were able to elevate the level of polysaccharide, the primary metabolic substrate during early estivation, by feeding snails ad libitum in the laboratory prior to estivation. Subsequently, when these snails were allowed to estivate, polysaccharide stores lasted longer, and mortality in both species was lower than when snails collected from the field
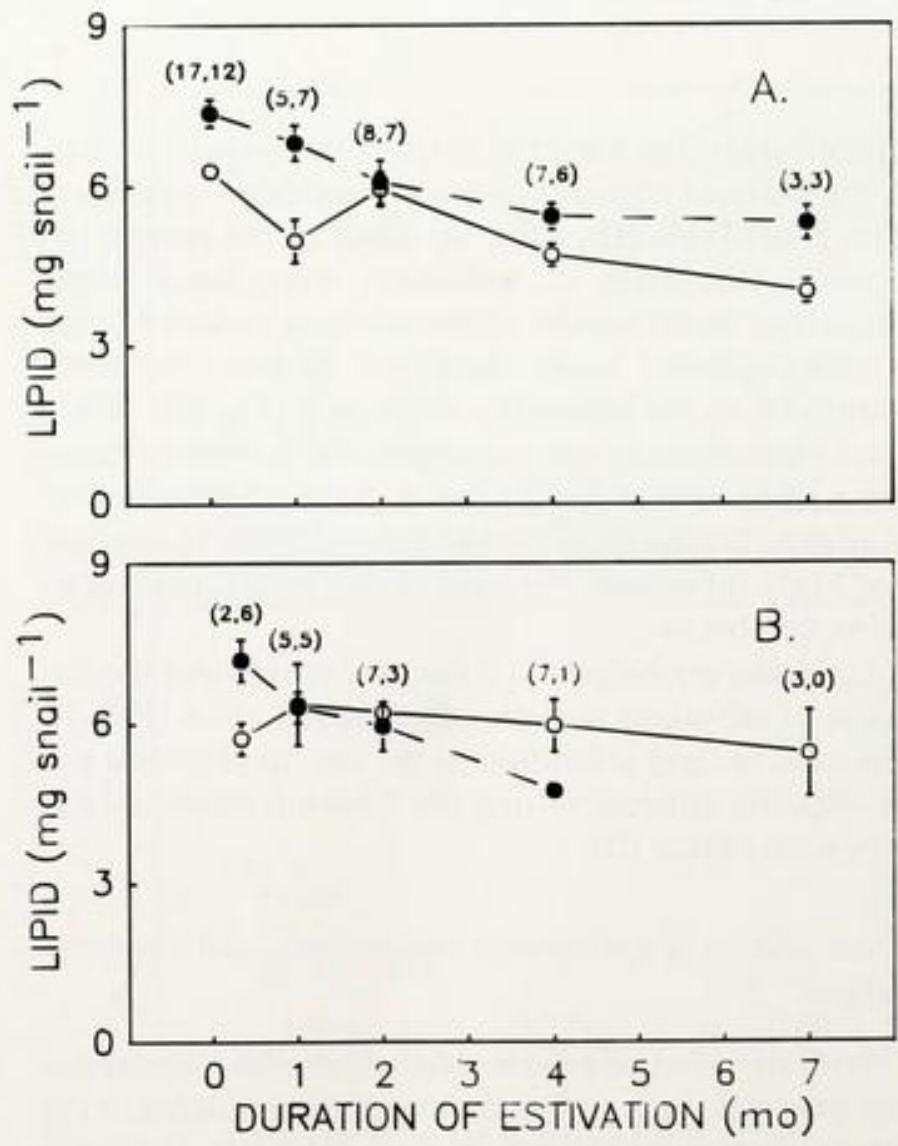

Figure 4. Lipid content during estivation in $O$ strigos $a(O)$ and $O$ subrudis (-). All values have been adjusted to a snail of average size based upon shell diameter. A. Laboratory-maintained snails. B. Fieldcollected snails. Sample sizes are given in parentheses with the value for $O$ strigosa appearing first. Bars indicate one standard error of the mean. 
estivated without prior laboratory feeding. In addition, among the field-collected snails. $O$. strigosa began with higher polysaccharide levels than $O$. subrudis, and the former displayed only half the mortality by 7 months of estivation. With data from four groups of snails ( 2 species $\times 2$ experimental series), we tested the correlation between pre-estivation polysaccharide stores and percent mortality at 7 months of estivation. Since snails with higher polysaccharide stores were predicted to survive estivation better (i.e., show lower mortality), the test was one-tailed. The negative correlation between pre-estivation polysaccharide stores and mortality was statistically significant ( $\mathrm{r}=-0.91, P=0.045)$. The observation that polysaccharide stores were exhausted several months prior to the onset of mortality, however, suggests that mortality is not due to the depletion of this substrate in sensu stricto. Rather, the correlation between polysaccharide stores and mortality likely reflects other biochemical changes that are initiated upon the depletion of the polysaccharide reserves (see below).

\section{Mortality and the accumulation of nitrogenous end-products}

Upon the exhaustion of polysaccharide, protein was catabolized, and both $O$. strigos $a$ and $O$. subrudis were found to accumulate urea as the major product of protein metabolism. Based upon rates of protein catabolism and end-product accumulation during the estivation interval of net protein depletion (2-7 months for laboratorymaintained snails and 10 days -7 months for field-collected snails), urea accumulation in the tissues accounted for approximately $50 \%$ of the nitrogen derived from protein catabolism, whereas the accumulation of purines only accounted for about $10 \%$ of the protein nitrogen. Ammonia production was below measurable levels, corresponding to less than $1 \%$ of the calculated nitrogen liberated from protein catabolism. A portion of the unaccounted fraction of nitrogen was probably lost during sample preparation (blotting of hemolymph can account for the loss of up to $25 \%$ of the urea nitrogen), and nitrogen may have accumulated in compounds not measured in this study (e.g., amino acids; c.f., Wieser and Schuster, 1975). Further studies of nitrogenous compounds in hemolymph of estivating snails may elucidate the nature of the missing nitrogen fraction.

In both experimental series, the rate of tissue urea accumulation was found to be faster in $O$. subrudis than in $O$. strigosa, resulting in higher urea contents in the former species. Because urea can easily cross most cell membranes (Forster and Goldstein, 1976), the urea measured in extracts of whole snails is likely to be uniformly distributed throughout the tissues of the snails. This assumption was supported by measuring urea in hemolymph, foot muscle
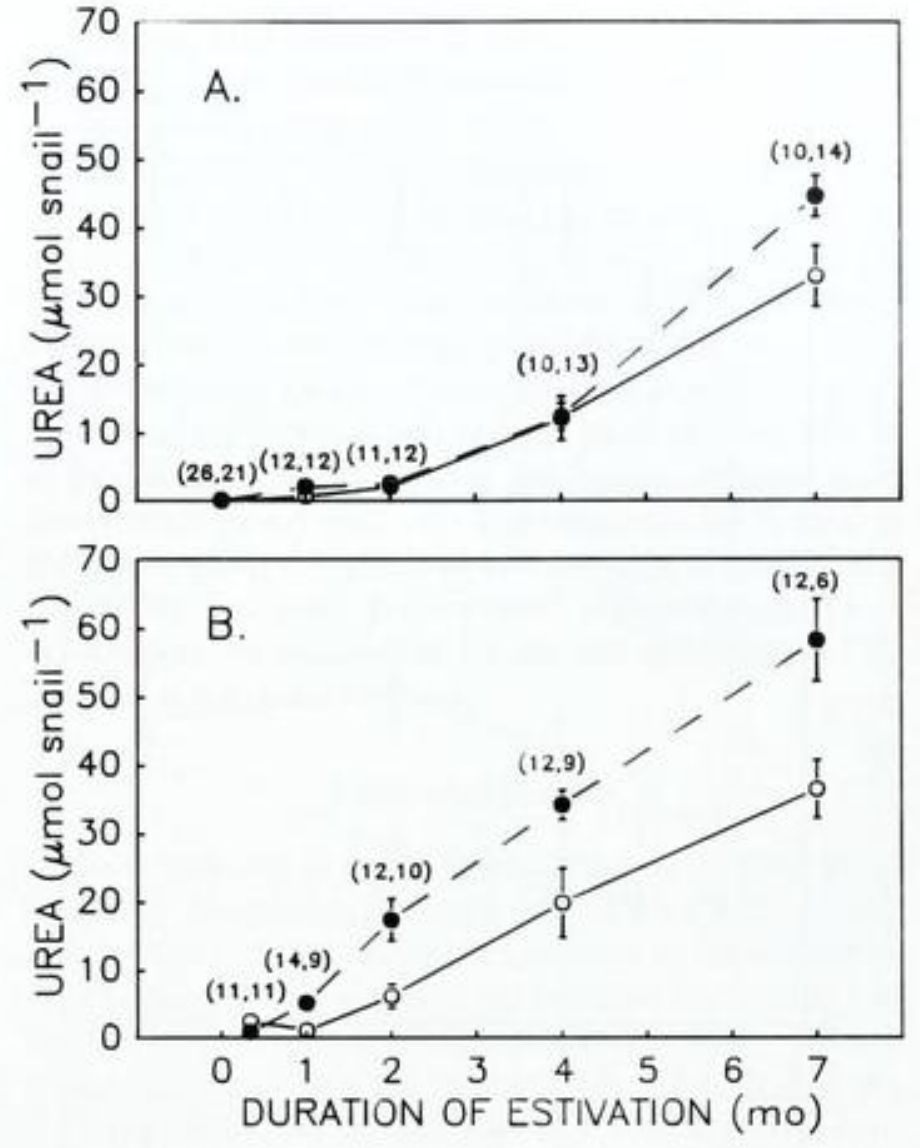

Figure 5. Urea content during estivation in $O$ strigosa $(O)$ and $O$ subrudis (-). All values have been adjusted to a snail of average size based upon shell diameter. A. Laboratory-maintained snails. B. Fieldcollected snails. Sample sizes are given in parentheses with the value for $O$ strigosa appearing first. Bars indicate one standard error of the mean.

and digestive gland of two laboratory-maintained $O$. strigosa after 7 months of estivation. In one snail, the urea concentrations were 131,126 , and $130 \mathrm{mM}$ in hemolymph, foot muscle, and digestive gland, respectively, and the other snail had urea concentrations of 211,155 , and $198 \mathrm{~m} M$ in these tissues. When urea concentrations were calculated for all snails based upon a uniform distribution in the total tissue water, urea was found to rise from less than $1 \mathrm{mM}$ prior to estivation to levels exceeding 150 $\mathrm{m} M$ by 7 months. The average urea concentrations in snails that had been estivating for 7 months were: 152 $\pm 24 \mathrm{~m} M(\mathrm{n}=10)$ and $204 \pm 14 \mathrm{mM}(\mathrm{n}=14)$ in laboratory-maintained $O$. strigos $a$ and $O$. subrudis, respectively, and $203 \pm 15 \mathrm{mM}(\mathrm{n}=12)$ and $288 \pm 27 \mathrm{mM}(\mathrm{n}$ $=6$ ) in the two species when field-collected snails were used. When tested with correlation analysis, a significant positive correlation was found between tissue urea concentration and mortality at 7 months in the four groups of snails $(\mathrm{r}=0.99, P=0.006)$. In a recent study of mammalian cells in culture, Yancey and Burg (1990) showed a dramatic decrease in viability as the urea concentration 

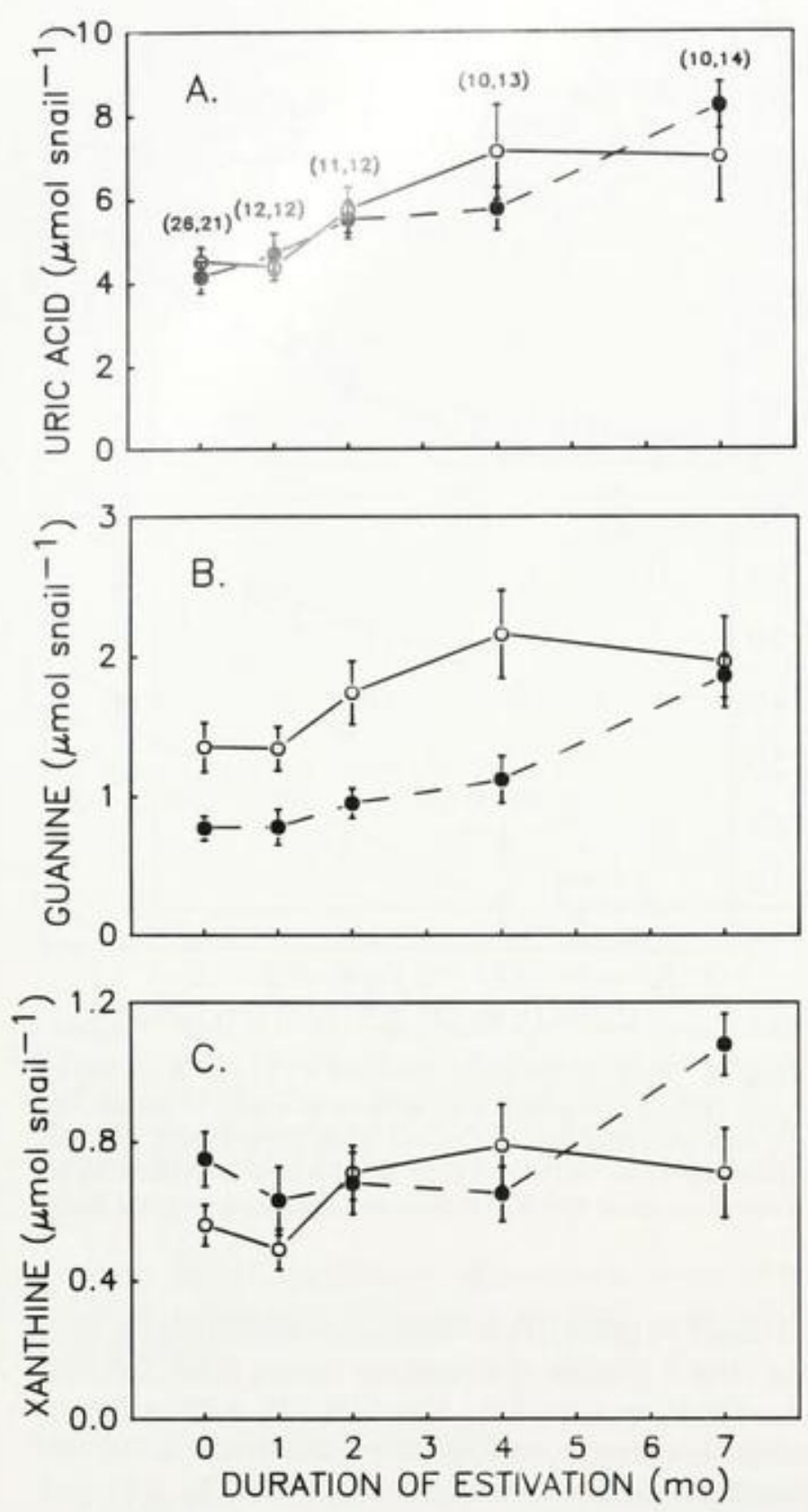

Figure 6. Purine content during estivation in $O$ strigosa $(O)$ and $O$. subrudis ( ). Measurements were only made with snails that had been maintained in the laboratory prior to estivation. All values have been adjusted to a snail of average size based upon shell diameter. A. Urate content. B. Guanine content. C. Xanthine content. Sample sizes are given in $6 \mathrm{~A}$ in parentheses with the value for $O$ strigosa appearing first. Bars indicate one standard error of the mean.

in the medium increased from 150 to $300 \mathrm{mM}$, the same range of concentrations across which survivorship decreased sharply in Oreohelix.

In other organisms that accumulate high levels of urea, there are also high levels of compounds that are capable of counteracting the potentially deleterious effects of urea (Yancey et al., 1982; Yancey, 1985). For example, in elas- mobranch fish, which display a tissue concentration of urea in this range, methylamine compounds occur in a 1:2 proportion with urea. At this ratio, methylamines are able to counteract the disruptive effects of high urea in vitro and are presumed to act this way in vivo. The methylamine content of estivating $O$. strigosa was low relative to urea. If methylamines were distributed uniformly in the tissue water, then their concentration would correspond to $12.2 \pm 1.9 \mathrm{mM}$. If methylamine compounds are concentrated intracellularly, as suggested by work with mammalian cells (Yancey and Burg, 1990), the intracellular concentration can approach $25 \mathrm{mM}$. Relative to the urea measured at this point in estivation, however, even $25 \mathrm{~m} M$ methylamines is far below the ratio of $1: 2$ at which methylamine effects counteract the perturbation of macromolecules by urea.

Thus, we offer the hypothesis that urea toxicity is a factor that limits the duration of estivation that can be tolerated by these two species of land snail. While higher levels of urea have been reported in other species of land snail (DeJorge and Peterson, 1970; Horne, 1971; Trammel and Campbell, 1972), in the absence of data on mortality and methylamine concentrations, we cannot evaluate the applicability of this hypothesis to these species. This hypothesis does not exclude the involvement of other factors (e.g. blood gases, $\mathrm{pH}$ or osmolarity) in setting the upper limit to estivation in these or other snails.

\section{Biological rationale for urea accumulation}

If urea does reach toxic levels, then it raises the question: why do estivating snails synthesize urea? One explanation is that the high tissue concentration of urea aids in water retention in arid environments (Horne, 1971). This explanation is unlikely, though, for two reasons. First, urea concentrations of $300 \mathrm{mM}$ only contribute a trivial amount to the gradient for water movement between the tissues and dry air (Machin, 1975). Secondly, urea accumulates faster in humid environments than in dry ones (Horne, 1973a). The osmotic effect of elevated urea could be beneficial in the uptake of water when conditions of high humidity return (Riddle, 1983).

Alternatively, the synthesis of urea may simply serve as a means of ammonia detoxification. The $\mathrm{LD}_{50}$ for ammonia in the land snail Bulimulus dealbatus is approximately $16 \mu \mathrm{mol} \mathrm{g}^{-1}$ wet weight (Horne, 1973b). Based upon rates of protein catabolism measured for Oreohelix species during estivation, this amount of ammonia is generated within 8 days. Clearly, if these snails are similarly sensitive to ammonia toxicity, then during prolonged periods of high protein catabolism, ammonia must be removed. By producing the moderately less toxic urea, snails may be able to carry out protein catabolism for a longer period. But $O$. strigosa and $O$. subrudis, as well as other 
species that accumulate urea during estivation. appear to have the capacity to synthesize purines as nitrogenous wastes, a class of compounds considered completely innocuous. It is a paradox that urea synthesis, rather than purine synthesis, is the primary pathway for ammonia detoxification in these snails during estivation. Perhaps urea synthesis is a compromise between the toxicity of the terminal end-product and the loss of organic carbon and energy equivalents, both of which are greater in purine synthesis.

\section{Ecological implications of differential mortality during laboratory estivation}

Previous studies have demonstrated that species of land snail that are more tolerant of desiccation under laboratory conditions are typically found in more arid habitats in nature (Machin, 1967; Cameron, 1970; Arad et al., 1989). While the ecologies of $O$. strigosa and $O$. subrudis have not been studied in depth, our data describe the climatic conditions and the species distributions at three sites in western Colorado. Based upon summer temperatures, relative humidities, and precipitation, moisture availability at these three sites decreases in the order Mitchell Creek $>$ Rifle Falls $>$ Rifle Gorge (see Materials and Methods; Table I). At the driest site, $O$. strigosa constitutes more than $60 \%$ of the snails collected (Fig. 7), suggesting that tolerance to prolonged estivation may influence the distribution of these species of land snail in nature. While $O$. strigosa is the predominant species at the Rifle Gorge site, $O$ subrudis does constitute nearly $40 \%$ of the snails collected at this dry site. The survival of $O$. subrudis, despite its lower tolerance to estivation under laboratory

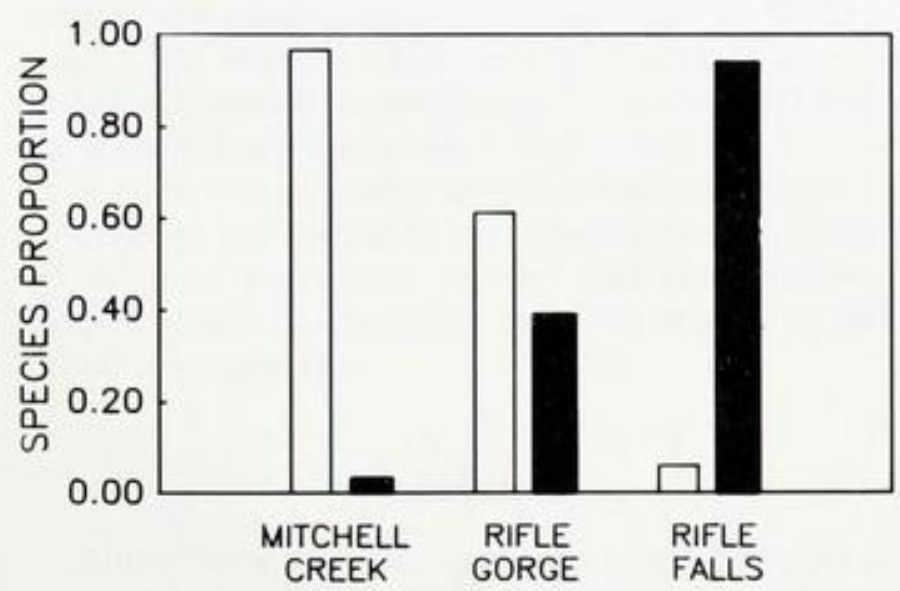

Figure 7. Distribution of $O$ strigosa (open bars) and $O$. subrudis (solid bars) at three collection sites in western Colorado. Data from the present study have been pooled with previous work (Rees, 1988; and unpub. obs.). Sample sizes were 157, 103, and 115 snails from the Mitchell Creek, Rifle Gorge, and Rifle Falls collection sites. At each site, the species proportions are significantly different from a uniform distribution (G-tests, $P<0.05$ ). conditions, may be related to selection of moister microhabitats, as described for land snail species of the Middle Eastern deserts (Arad et al., 1989).

The other two sites were more mesic, and they were dominated by either $O$. strigos $a$ (Mitchell Creek) or $O$. subrudis (Rifle Falls) (Fig. 7). Because the potential for desiccation stress is probably lowest at the Mitchell Creek site, the low abundance of $O$. subrudis at this site cannot be attributed to a lower tolerance of desiccation. Rather, other factors, either physical (e.g., calcium availability) or biological (e.g., differential predation, different food preferences, or random effects associated with founding the colony), may explain their low numbers at the Mitchell Creek site. Similarly, factors other than desiccation tolerance must be responsible for the low abundance of $O$. strigos $a$ at the Rifle Falls site.

\section{Acknowledgments}

We would like to thank Mark Losleben (University of Colorado Mountain Research Station) and Drs. Jeffry Mitton and Cynthia Carey (Department of Environmental, Population and Organismic Biology) for the loan of various pieces of equipment used in this study. We are grateful to the staff of the Mitchell Creek and Rifle Falls Fish Hatcheries for allowing us to record climatic conditions at their facilities. Dr. Paul Yancey (Whitman College) is acknowledged for kindly performing the HPLC analyses of methylamine and polyol compounds. We also thank Dr. Michael Grant (EPO Biology) for statistical advice and Dr. Shi-Kuei Wu (University of Colorado Museum) for his help in locating populations of Oreohelix strigosa and $O$. subrudis. Financial support for this research was provided by the Kathy-Lichty Award for Graduate Student Research and a National Science Foundation Graduate Fellowship to BBR and NSF grants DCB-8702615 and DCB-9018579 to SCH.

\section{Literature Cited}

Arad, Z, S. Goldenberg, and J. Heller. 1989. Resistance to desiccation and distribution patterns in the land snail Sphincterochila. I. Zool Lond 218: $353-364$.

Barnhart. M. C. 1986. Respiratory gas tensions and gas exchange in active and dormant land snails, Otala lactea. Physiol. Zool. 59: 733745 .

Bequaert, J. C., and W. B. Miller. 1973. The Mollusks of the Arid Southwest University of Arizona Press, Tucson, AZ.

Bishop, S. H. L. L. Ellis, and J. M. Burcham. 1983. Amino acid metabolism in Molluses. Pp. 243-327 in The Mollusca. vol. 1. P. W, Hochachka, ed. Academic Press, NY.

Burton, K. 1956. A study of the conditions and mechanism of the diphenylamine reaction for the colorimetric estimation of deoxyribonucleic acid. Biochem. J. 62: 315-323.

Cameron, R. A. D. 1970. The survival, weight-loss and behaviour of three species of land snail in conditions of low humidity. $I$ Zool. Lond 160: 143-157. 
DeJorge, F. B., and J. A. Peterson. 1970. Urea and uric acid contents in the hepatopancreas, kidney and lung of active and dormant snails. Strophocheilus and Thatumastus (Pulmonata. Mollusca). Comp. Biochem. Physiol. 35: 211-219

Folch, J., M. Lees, and G. H. S. Stanley. 1957. A simple method for the isolation and purification of total lipides from animal tissues. $J$ Biol. Chem. 226: 497-509.

Forster, R. P., and L. Goldstein. 1976. Intracellular osmoregulatory role of amino acids and urea in marine elasmobranchs. $A m$. J. Physiol. 230: $925-931$

Giles, K. W , and A. Myers. 1965. An improved diphenylamine method for the estimation of deoxyribonucleic acid. Nature 206: 93.

Herreid, C. F., III. 1977. Metabolism of land snails (Otala lactea) during dormancy, arousal, and activity. Comp. Biochem. Physiol 56A: 211215.

Horne, F, R. 1971. The accumulation of urea by a pulmonate snail during estivation. Comp. Biochem. Physiol. 38. A: 565-570.

Horne, F. R. 1973a. The utilization of foodstuffs and urea production by a land snail during estivation. Biol. Bull 144: $321-330$.

Horne, F. R. 1973b. Urea metabolism in an estivating terrestrial snail Bulimulus dealbatus. Am I. Phrsiol 224: 781-787

Jermyn, M. A. 1975. Increasing the sensitivity of the anthrone method for carbohydrate. Anal. Biochem. 68:332-335.

Jezewska, M. M., B. Gorzkowski, and J. Heller. 1963. Nitrogen compounds in snail Helix pomatia excretion. Acta Biochim. Polonica 10: 55-64.

Kermack, W. O., H. Lees, and J. D. Wood. 1955. Some non-protein constituents of the tissues of the lobster. Blochem. J. 60: 424-428.

Koch, F. C., and T, L. McMeekin. 1924. A new direct nesslerization micro-Kjeldahl method and a modification of the Nessler-Folin reagent for ammonia. J Am. Chem. Soc 46: 2066-2069.

Lowry, O. H., N. J. Rosebrough, A. L. Farr, and R. J. Randall. 1951. Protein measurement with the Folin phenol reagent. $J$. Biol. Chem. 193: 265-275.

Machin, J. 1967. Structural adaptation for reducing water-loss in three species of terrestrial snail. $J$. Zool. Lond 152: 55-65.

Machin, J. 1975. Water relationships. Pp. 105-163 in The Pulmonates, vol. I. V. Fretter and J. Peake, eds. Academic Press, NY.

Peterson, G. L. 1977. A simplification of the protein assay method of Lowry et al. which is generally more applicable. Anal. Biochem. 83: $346-356$
Pomeroy, D. E. 1969. Some aspects of the ecology of the land snail. Helicella virgata, in South Australia. Aust / Zool 17:495-514.

Rees, B. B. 1988. Electrophoretic and morphological characteristics of two species of Oreohelix, the Mountain Snail. Malacol. Rev. 21: 129 132.

Rees, B. B., and S. C. Hand. 1990. Heat dissipation, gas exchange and acid-base status in the land snail Oreohelix during short-term estivation. J Exp. Biol. 152: 77-92.

Riddle, W. A. 1983. Physiological ecology of land snails and slugs. Pp. 431-461 in The Mollusca, vol 6, W. D. Russell-Hunter, ed. Academic Press, NY

Schmidt-Nielsen, K., C. R. Taylor, and A. Shkolnik. 1971. Desert snails problems of heat, water and food. I. Exp. Biol. 55: 385-398.

Simmonds, R. J., and R. A. Harkness. 1981. High-performance liquid chromatography for base and nucleoside analysis in extracellular fluids and in cells. I. Chromatog. 226: 369-381

Speeg, K. V., Jr., and J. W. Campbell. 1968. Formation and volatil. ization of ammonia gas by terrestrial snails. Am. $J$ Phisiol 214: $1392-1402$

Stearns, R. E. C. 1877. On the vitality of certain land mollusks. Am Nat. 2: 100-102.

Trammel, P. R., and J. W. Campbell. 1972. Arginine and urea metabolism in the South American land snail, Strophocheilus oblongus Comp Biochem. Physiol 42B: 439-449.

Ways, P... and D.J. Hanahan. 1964. Characterization and quantification of red cell lipids in normal man. $J$. Lipid Res. 5: $318-328$.

Wieser, W., and M. Schuster. 1975. The relationship between water content, activity, and free amino acids in Hefix pomatia. J. Comp Physiol 98: 169-181.

Yancey, P. H. 1985. Organic osmotic effectors in cartilaginous fishes. Pp. 424-436 in Transport Processes, lono- and Osmoregulation, R. Gilles and M. Gilles-Baillien, eds, Springer-Verlag, Berlin.

Yancey, P. H. M. E. Clark, S. C. Hand, R. D. Bowlus, and G. N. Somero. 1982. Living with water stress: evolution of osmolyte systems, Science 217: 1214-1222

Yancey, P. H., and M. B. Burg. 1990. Counteracting effects of urea and betaine in mammalian cells in culture. $A m$. I. Physiol 258: R 198R204.

Zar, J. H. 1984. Biostatistical Analysis. Prentice-Hall, Inc., Englewood Cliffs, NJ. 